\title{
Resistance to Phytophthora Species among Rootstocks for Cultivated Prunus Species
}

\author{
Gregory T. Browne ${ }^{1}$ \\ Department of Plant Pathology, USDA-ARS, Crops Pathology and Genetics \\ Research Unit, University of California, Davis, CA 95616
}

Additional index words. Almond, fruit, nut, Prunus, hybrid, Phytophthora

\begin{abstract}
Many species of Phytophthora de Bary are important pathogens of cultivated Prunus L. species worldwide, often invading the trees via their rootstocks. In a series of greenhouse trials, resistance to Phytophthora was tested in new and standard rootstocks for cultivated stone fruits, including almond. Successive sets of the rootstocks, propagated as hardwood cuttings or via micropropagation, were transplanted into either noninfested potting soil or potting soil infested with Phytophthora cactorum (Lebert \& Cohn) J. Schöt., Phytophthora citricola Sawada, Phytophthora megasperma Drechs, or Phytophthora niederhauserii Z.G. Abad \& J.A. Abad. Soil flooding was included in all trials to facilitate pathogen infection. In some trials, soil flooding treatments were varied to examine their effects on the rootstocks in both the absence and presence of Phytophthora. Two to 3 months after transplanting, resistance to the pathogens was assessed based on the severity of root and crown rot. 'Hansen 536' was consistently more susceptible than 'Lovell', 'Nemaguard', 'Atlas', 'Viking', 'Citation', and 'Marianna 2624 ' to root and/or crown rot caused by $P$. cactorum, $P$. citricola, and $P$. megasperma. By contrast, susceptibility to $P$. niederhauserii was similarly high among all eight tested genotypes of peach, four genotypes of peach $\times$ almond, two genotypes of (almond $\times$ peach) $\times$ peach, and one genotype of plum $\times$ almond. Most plum hybrids were highly and consistently resistant to crown rot caused by $\boldsymbol{P}$. niederhauserii, but only 'Marianna 2624' was highly resistant to both crown and root rot caused by all of the Phytophthora species. The results indicate that there is a broad tendency for susceptibility of peach $\times$ almond rootstocks and a broad tendency for resistance of plum hybrid rootstocks to multiple species of Phytophthora.
\end{abstract}

More than 10 species of Phytophthora de Bary are reported to affect cultivated Prunus L. worldwide, causing root rot, crown rot, trunk and scaffold cankers, and even fruit rots (Browne and Doster, 2002; Browne and Mircetich, 1995; Félix-Gastélum and Mircetich, 2005a; Guzman et al., 2007; Harvey and Braithwaite, 1982; Wicks and Lee, 1986; Wilcox and Ellis, 1989; Wilcox and Mircetich, 1985). In California alone, $\approx 400,000$ ha of land are devoted to almond and stone fruit culture (NASS, 2015), and root and crown rots caused by Phytophthora are a major concern in the production systems (Browne et al., 1998; Browne and Viveros, 1999). Intensive irrigation is critical to culture these crops in California because of the dry summer climate. Despite its necessity, irrigation can sometimes contribute to development of Phytophthora diseases, both by spreading the pathogens over long distances

Received for publication 3 Nov. 2017. Accepted for publication 18 May 2017

I thank the Dave Wilson Nursery, Duarte Nursery, and North American Plants for their help in propagating rootstock material used in this work.

${ }^{1}$ Corresponding author. E-mail: Gregory.Browne@ ars.usda.gov.

This is an open access article distributed under the CC BY-NC-ND license (http://creativecommons. org/licenses/by-nc-nd/4.0/). through surface water supply networks of rivers and canals and by favoring production, dispersal, and infection by the pathogens' zoospores (Browne et al., 2012; Félix-Gastélum and Mircetich, 2005a).

Although species of Phytophthora can infect Prunus scions directly, Prunus rootstocks are often infected first, sometimes providing the route to further pathogen ingress into a tree (Browne and Viveros, 1999). Phytophthora cactorum (Lebert \& Cohn) J. Schöt. and Phytophthora megasperma Drechs. were often associated with root and crown rots and trunk cankers resulting from subterranean infections, whereas Phytophthora citricola Sawada tended to invade almond scions directly, aboveground (Browne et al., 1998; Browne and Viveros, 1999). Recently, Phytophthora niederhauserii Z.G. Abad \& J.A. Abad. was described (Abad et al., 2014) and reported as a new root and crown pathogen of almond nursery trees in Spain (Pérez-Sierra et al., 2010) and almond orchard trees in Turkey (Kurbetli; and Değirmenci, 2012) and California (Browne et al., 2015a).

Rootstock improvement will continue to be essential for sustaining efficient, profitable cultivation of Prunus spp. (Gradziel, 2009; Moreno, 2004; Reighard et al., 1989). In California and other regions where Prunus species have been cultivated through many generations on the same land, effective rootstocks must resist or tolerate accumulations of soil pests while maintaining appropriate levels of scion vigor and productivity. Depending on the challenges presented by an orchard site, prudent rootstock selection tends to be a compromise, balancing horticultural attributes and edaphic adaptations (i.e., level of vigor, sensitivity to salts or high $\mathrm{pH}$, etc.) with resistance or tolerance to soilborne pathogens (e.g., Phytophthora species, plant parasitic nematodes, and Armillaria spp.), and one rootstock seldom meets all needs. Advances in rootstock breeding and micropropagation technologies have expanded improvement horizons for Prunus rootstocks, yet fully realizing the potential of these advances will require continuing and accurate assessments of rootstock traits.

Variation in resistance to Phytophthora has been reported previously among rootstocks for Prunus species (Broadbent et al., 1996; Day, 1953; Elena and Tsipouridis, 2000; Kester and Grasselly, 1987), but for many new clonal rootstocks, little is known about their relative susceptibility to Phytophthora species. Furthermore, $P$. niederhauserii was reported to attack almond and peach $\times$ almond hybrid rootstocks (Browne et al., 2015a; Kurbetli; and Değirmenci, 2012; Pérez-Sierra et al., 2010), but the relative susceptibility to this pathogen among other Prunus rootstocks is unknown. The purpose of this research was to examine resistance to historically prevalent as well as newly recognized species of Phytophthora in standard and recently developed rootstocks for stone fruit production. Preliminary aspects of this work have been reported (Browne and Becherer, 2000; Schmidt et al., 2012).

\section{Materials and Methods}

Plant materials and culture. Twenty-five rootstock selections in total, propagated as either hardwood cuttings or micropropagated plantlets, were provided in sets by three commercial nurseries (Table 1). The rootstocks in each set were selected to represent widely used standard rootstocks as well as new rootstocks of interest, especially those potentially suited to the challenges of California fruit and nut production.

All hardwood cuttings were obtained through nursery 1 (Dave Wilson Nursery, Hickman, CA). The cuttings, made from "well-hardened" current-season shoots in late October, were 0.5 to $1 \mathrm{~cm}$ in diameter and $\approx 30 \mathrm{~cm}$ in length. Those of 'Lovell' and 'Nemaguard' were collected from the University of California Foundation Plant Service block at Davis, CA, whereas cuttings of the other selections were made from proprietary foundation blocks of the nursery. All cuttings were treated with a basal dip of indole butyric acid (500 to $1000 \mathrm{ppm}$ ) and callused for 1 month in moist peatmoss at nursery 1 . In November, the callused cuttings were planted into $5 \times 5 \times 25 \mathrm{~cm}$ cartons with UC potting mix (Matkin et al., 1957), one cutting per carton, at UC Davis. After planting, 
Table 1. Trials and plant materials

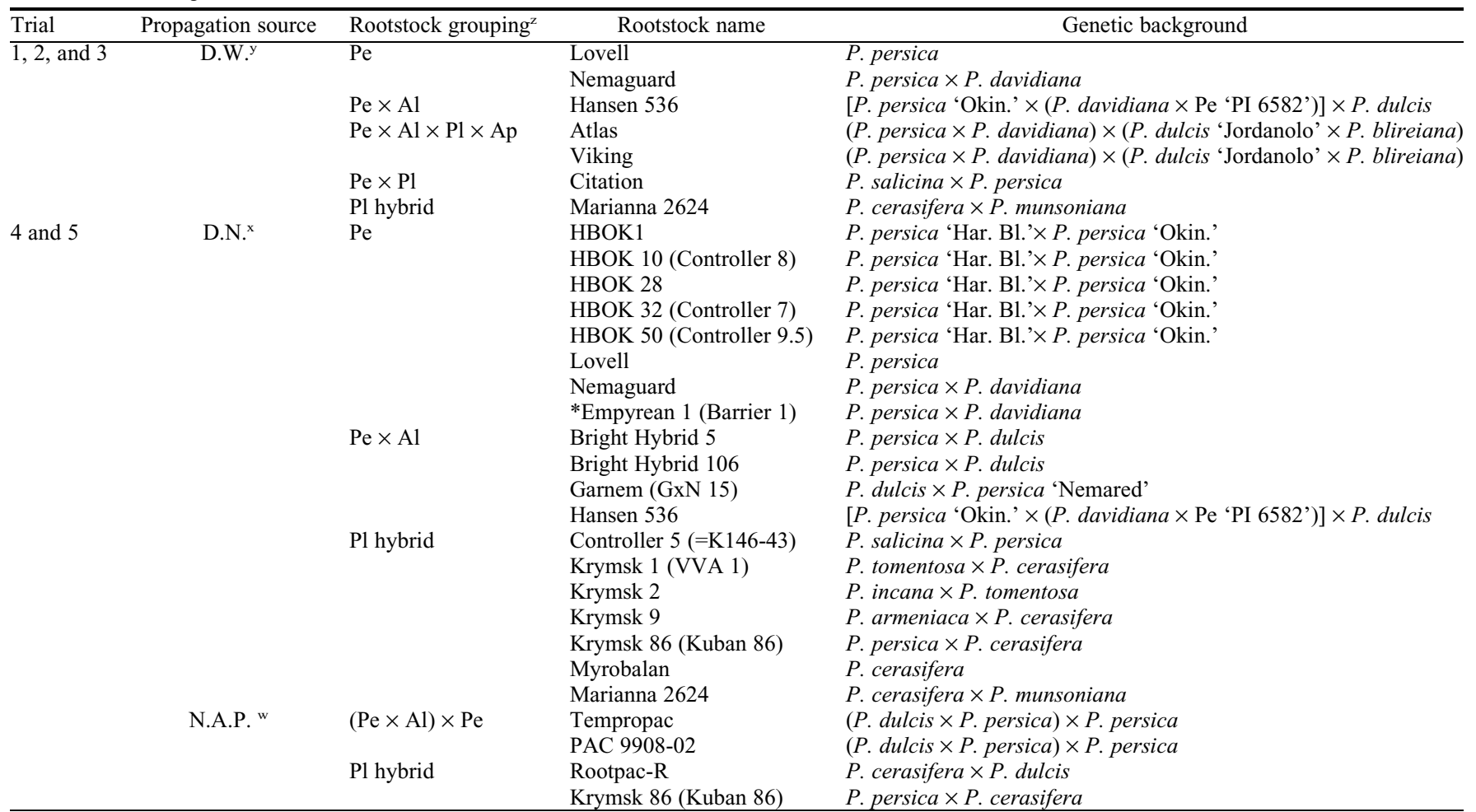

${ }^{\mathrm{Z}} \mathrm{Pe}=$ peach $; \mathrm{Al}=$ almond; $\mathrm{Pl}=$ plum; $\mathrm{Ap}=$ apricot.

${ }^{\mathrm{y}}$ Dave Wilson Nursery; Hickman, CA, nursery 1.

${ }^{\mathrm{x}}$ Duarte Nursery, Hughson, CA, nursery 2.

w North American Plants, Inc., Lafayette, OR, nursery 3.

about half to $2 / 3$ of the cutting length was covered with the potting mix in the cartons. The plants were kept in a lathhouse through the winter. The plants were used for experiments 1 to 3 , as described in the following section.

The micropropagated plants were provided by nurseries 2 and 3 (Duarte Nursery, Hughson, CA, and North American Plants, Inc., Lafayette, OR, respectively). The plants were micropropagated according to the nurseries' proprietary procedures and provided in $2 \times 4 \mathrm{~cm}$ pots in an actively growing state, with stems 3 to $5 \mathrm{~mm}$ in diameter and main shoots $\approx 7$ to $10 \mathrm{~cm}$ tall. The plants were used for experiments 4 and 5, as described in the following section.

In all experiments, the plants were watered as needed, up to once per day. In treatments that involved soil flooding, the soil water level was maintained at $\approx 1 \mathrm{~cm}$ above the potting soil surface for the specified flooding period(s). All plants were fertilized one to two times per week using a modified Hoagland solution (Hoagland, 1928).

Isolates and inocula of Phytophthora. Phytophthora species prevalent among almond and other stone fruit orchards affected by crown and root rot in California were obtained by culturing necrotic bark and root pieces in a modified PARP medium (Browne et al., 2015b; Kannwischer and Mitchell, 1978). The isolates were identified based on their morphological characteristics (e.g., culture morphology, and production and morphology of sporangia, chlamydospores, and oospores) and confirmatory sequencing of internal transcribed spacer (ITS) regions 1 and 2 of rRNA genes. In all trials, the pathogen inocula were grown for 4 to 5 weeks at 20 to $24{ }^{\circ} \mathrm{C}$ on a substrate of vermiculite and oat seeds drenched in a broth containing V8 juice (standard V8 juice; Campbell Soup Co., Camden, NJ). The substrate was prepared and used as described previously (Browne et al., 2015b). Individual isolates were grown in separate containers of the substrate, and sterile substrate served as the control. Just before infestation of the potting soil used in greenhouse evaluations of resistance, all inocula and the control were rinsed thoroughly in sterile water to remove unassimilated nutrients. Two to five isolates were used per species of Phytophthora in each experiment. In experiments 1 through 3 and 5 , isolates of the same species were pooled just before addition to soil. In experiment 4 , isolates were kept separate as treatments.

Greenhouse evaluations of resistance to Phytophthora. For trial 1, hardwood cuttings rooted in the lathhouse during the winter and spring were transplanted the following June into $9 \times 9 \times 23 \mathrm{~cm}$ pots with either noninfested UC potting mix or UC potting mix infested with isolates of $P$. cactorum, $P$. citricola, or $P$. megasperma. One plant was transplanted into each pot. The "root ball" and surrounding potting soil of the rooted cuttings were left intact in the transplanting process, and $1 \mathrm{~L}$ of infested or noninfested potting soil was added to the pots receiving the plants. Before the soil was added to the pots during transplanting, it was mixed with the appropriate amount of inoculated or sterile substrate to achieve a rate of $40 \mathrm{~mL}$ of substrate per liter of total soil volume in pots. Combinations of inoculum and soil flooding treatments were assigned to main plots that were randomized in four complete blocks. Rootstocks were assigned to subplots within the main plots; there were two plants per rootstock in each main plot. Control main plots were flooded for $0 \mathrm{~h}$, $24 \mathrm{~h}$ once every week, or $48 \mathrm{~h}$ once every 2 weeks. Main plots inoculated with $P$. cactorum, $P$. citricola, or $P$. megasperma were flooded for $24 \mathrm{~h}$ (weekly) or $48 \mathrm{~h}$ (biweekly). Three months after transplanting, plants were washed free from their potting soil, and resistance to the pathogens was assessed based on the severity of crown and root rot.

For crown rot assessment, the root crown was considered to be the central root system axis and lower stem, starting from the point of main root convergence and extending to 3 $\mathrm{cm}$ above the soil surface. On each diseased root crown, a knife was used to reveal boundaries of healthy bark (white under the outer corky layer) and necrotic bark (black to brown). The rotted and total lengths of each root crown were measured, and rotted crown length was expressed as a percentage of total crown length. The percentage of root length rotted was estimated visually; root length was considered rotted when the cortex and stele were necrotic (brown to black) as compared 
with healthy, light-colored tissues. Isolations were conducted from most plants to confirm the presence of the appropriate pathogen in inoculated treatments and the absence of the pathogen in control plants.

For trials 2 and 3, the plant materials were from the same set that supplied trial 1 , but they were 8 and 13 months older, respectively, at the time of trial establishment. During the extra 8-13 months, trials 2 and 3 plants were kept in a greenhouse in spring and summer months and in a lathhouse in winter months. Before placement in the lathhouse for the additional winter, each plant pot received $\approx 15 \mathrm{~mL}$ of Osmocote slow-release fertilizer (The Scotts Company, Marysville, $\mathrm{OH}$; N-P-K 18-6-12) on the soil surface. The plants were returned to the greenhouse for trials in February. Subsequent procedures, treatments, and the experimental design used for trials 2 and 3 were the same as those used for trial 1, except as follows: soil given the control inoculation treatment received only nonflooded and 48-h flood treatments; only $P$. cactorum and $P$. megasperma were used as challenging pathogens; and only 48-h flood treatments were used for the soil treatments that received a species of Phytophthora. In addition, trials 2 and 3 included five replicate blocks per main plot treatment, and trial 2 had only one plant per rootstock per main plot.

Trial 4 was established with active micropropagated plants from nurseries 2 and 3 in late May. The rootstocks were transplanted into $600-\mathrm{mL}$ pots (one plant per pot) using UC potting mix. Three different inoculumsubstrate treatments were added to the soil during the planting process: 1) sterile substrate (the control), 2) substrate permeated with an isolate of $P$. niederhauserii from an almond tree near Shafter, CA (isolate 1), and 3) substrate permeated with a $P$. niederhauserii isolate from an almond tree near Sanger, CA (isolate 2). All substrate treatments were added at a rate of $40 \mathrm{~mL} \cdot \mathrm{L}^{-1}$ of final soil volume. The plants were allocated to main and subplots according to a split-plot design; main plots received the inoculum treatments and subplots received the different rootstocks. The main plots were randomized in five complete blocks, and each main plot included two plants per rootstock. Thus, there were 10 plants per combination of inoculum and rootstock treatment. One week after transplanting, and once every 2 weeks thereafter, all of the plants were subjected to $48 \mathrm{~h}$ of soil flooding. Two months after transplanting, all of the plants were washed free from their soil and rated for severity of crown and root rot as described for trial 1 .

Plants used for trial 5 were micropropagated and provided 1 year later than those used for trial 4 . In addition, the plants were transplanted into 0.7 -L pots and went through the summer and winter in a lathhouse before use in trial 5. In June, the 1-year-old plants were moved to a greenhouse for inoculation treatments. Soil inoculation treatments included a control, administered by inserting $10 \mathrm{~mL}$ of sterile inoculum substrate on two opposite sides of each plant pot (i.e., $20 \mathrm{~mL}$ total per pot per plant), and a $P$. niederhauserii treatment, administered by inserting $10 \mathrm{~mL}$ of the substrate colonized by five isolates of the pathogen on two opposite sides of each plant pot. There were six plants per rootstock per inoculum treatment. Again, a split-plot design was used, with inoculum treatments allocated to main plots and rootstocks allocated to subplots. The main plots were randomized in three complete blocks. Each main plot had two plants per rootstock subplot. All of the plants were subjected to $48 \mathrm{~h}$ of soil flooding once every 2 weeks. Two months after inoculation, the plants were washed free from their soil, weighed, and rated for severity of crown and root rot as described for trial 1 .

Data analyses. Data from each greenhouse trial were subjected to analysis of variance (ANOVA) using the MIXED procedure of SAS software Version 9.4. In preparation for ANOVA, the MEANS procedure of SAS was used to generate a mean for each combination of block, rootstock selection, soil flooding treatment, and disease assessment variable. ANOVAs were conducted separately for data from control (noPhytophthora) treatments and data from treatments including Phytophthora because of greater variance in the latter grouping compared with the former. For ANOVAs within these groupings, inoculum-flood treatment combinations and rootstock were specified as fixed effects in the MIXED model, and block and block $\times$ main plot treatments were specified as random effects, as appropriate.
Treatment means were separated according to $95 \%$ confidence intervals.

\section{Results}

In trial 1, conducted in June through early August with hardwood cuttings rooted the previous winter and spring, noninoculated controls developed negligible levels of root rot and no crown rot, regardless of the soil flooding treatment (Fig. 1A and B). By contrast, rootstocks exposed to Phytophthora developed varying severities of root and crown rot, depending on the species of Phytophthora and the soil flooding treatment. Significant statistical interaction occurred among Phytophthora $\times$ flooding treatments $(P<0.0001$ for both root and crown rot). In soil infested with $P$. cactorum, rootstocks developed negligible to moderate severities of root and crown rot $(0 \%$ to $38 \%$, depending on rootstock and flood duration; Fig. $1 \mathrm{~A}$ and B); 'Hansen 536' developed more root rot than some of the other rootstocks in soil infested with the pathogen and flooded biweekly for $48 \mathrm{~h}$. In soil infested with $P$. citricola, 'Hansen 536' developed severe root and crown rot (mean $71 \%$ to $100 \%$ ), more than any of the other rootstocks $(0 \%$ to $39 \%$ ), whether the soil was flooded for $24 \mathrm{~h}$ weekly or $48 \mathrm{~h}$ biweekly (Fig. 1A and B). Phytophthora megasperma caused moderate to high severities of root rot $(42 \%$ to $92 \%)$ and negligible to moderate levels of crown rot $(0 \%$ to $39 \%)$ in 'Lovell', 'Hansen 536 ', 'Atlas', and 'Viking'; on some of the stocks, the root rot severity was greater following
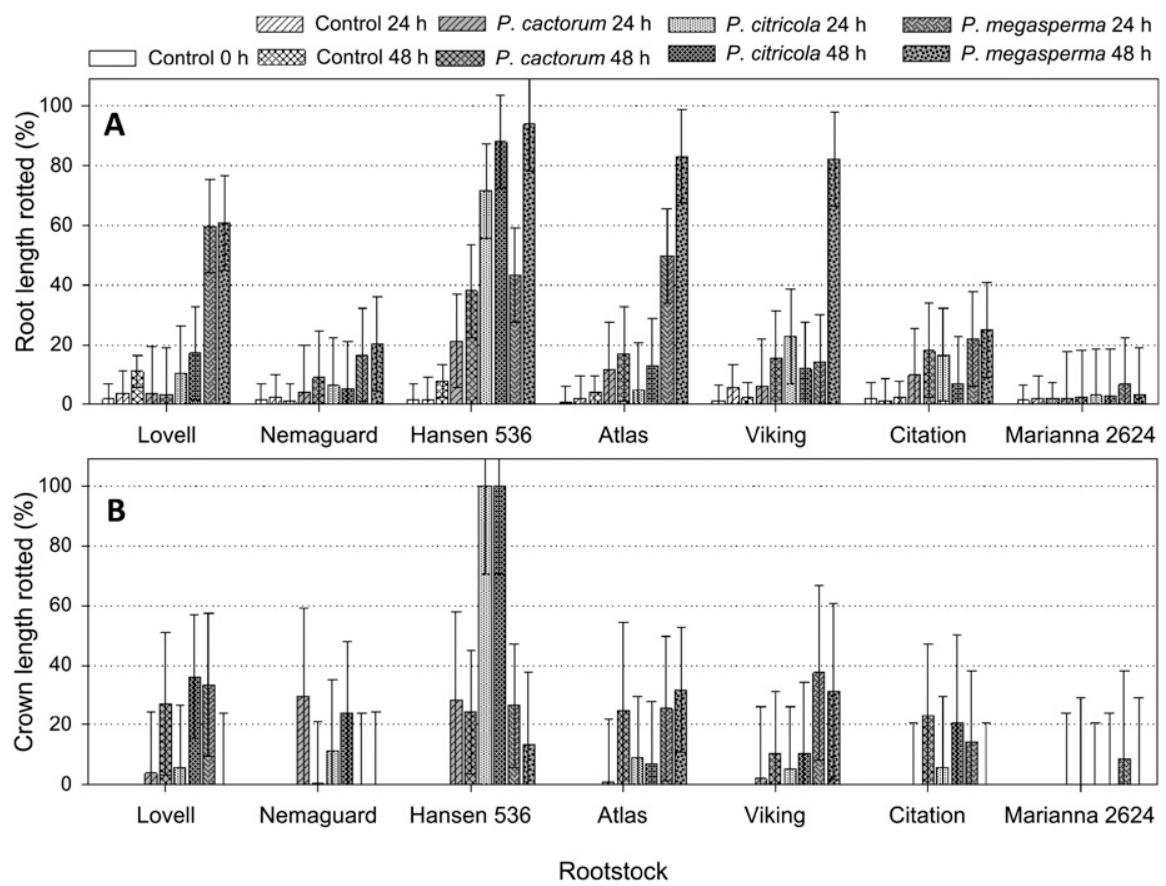

Fig. 1. Relative resistance of rootstocks in trial 1 to (A) root rot and (B) crown rot caused by three species of Phytophthora. The rootstocks were transplanted into noninfested soil (control) or soil infested with the indicated species of Phytophthora. Depending on the inoculum treatment, plants were either subjected to no soil flooding $(0 \mathrm{~h}$ ), weekly soil flooding for $24 \mathrm{~h}$, or biweekly soil flooding for $48 \mathrm{~h}$. Three months after transplanting, the rootstocks were washed free from the potting soil and evaluated for severity of root and crown rot. Error bars are $95 \%$ confidence intervals. 
48-h biweekly flooding than 24-h weekly flooding. Phytophthora megasperma caused relatively low severities $(<22 \%)$ of root and crown rot in 'Nemaguard', 'Citation', and 'Marianna 2624'. 'Marianna 2624' developed only negligible levels of root and crown rot, regardless of inoculant or soil flooding treatment.

In trial 2, which inoculated an additional set of plants from hardwood cuttings in spring, when they were 8 months older than those used for trial 1, plants in noninfested soil, whether flooded for 0 or $48 \mathrm{~h}$, developed only low levels of root rot and no crown rot (Fig. 2A and B). Again, as in trial 1, in soil infested with $P$. cactorum, only 'Hansen 536' developed severe levels of root or crown rot; 'Atlas' and 'Viking' developed less disease; and 'Lovell' and 'Nemaguard' developed negligible levels of root and crown rot with $P$. cactorum. Phytophthora megasperma caused high levels of root rot in all rootstocks except 'Citation' and 'Marianna 2624'. Phytophthora megasperma completely rotted the length of 'Hansen 536' root crowns, yet it caused only low to moderate amounts of crown rot on 'Lovell', 'Nemaguard', 'Atlas', and 'Viking'. Neither 'Citation' nor 'Marianna 2624' developed significant levels of root or crown rot in trial 2.

Results of trial 3, which inoculated a final subset of rooted hardwood cuttings in midsummer, when they were 13 months older than the rootstocks tested in trial 1 , were similar to those of trial 2 with respect to $P$. megasperma, but $P$. cactorum caused little disease in trial 3 (Fig. 3A and B). With $48 \mathrm{~h}$ of soil flooding, $P$. megasperma again caused severe root rot in all tested rootstocks except 'Citation' and 'Marianna 2624' ('Lovell' was not included in trial 3). Negligible root rot and no crown rot were caused by either $P$. cactorum or $P$. megasperma in 'Citation' and 'Marianna 2624'.

In trial 4, which involved the early summer inoculations with isolates of $P$. niederhauserii, there was no significant isolate $x$ rootstock interaction $(P=0.42$ to 0.72 with control data excluded), so mean separations were performed after combining data from the two isolates. Phytophthora niederhauserii caused relatively severe root rot in all rootstocks except 'Controller 5' and 'Marianna 2624' (Fig. 4A and B). The pathogen caused moderate to severe crown rot in selections without plum parentage (i.e., rootstocks HBOK 1, 10, 28, 32, 50; Lovell; Nemaguard; Empyrean 1; Bright Hybrid 5 and 106; Garnem; Hansen 536; Tempropac; and PAC 9908-02). Phytophthora niederhauserii caused little crown rot among the plum hybrids (i.e., rootstocks Controller 5; Krymsk 1, 2, 9, and 86; Myrobalan; Marianna 2624; and Rootpac-R).

In trial 5, rootstocks Krymsk 1, 2, 9, and 86, and Myrobalan, which had all developed moderate to severe root rot in trial 4 , developed little root rot (Fig. 5A and B). In addition, low to moderate crown rot severity generally developed in trial 5 for the selections of peach (i.e., rootstocks HBOK 1, 10, 28, 32, and 50; Lovell; Nemaguard; and
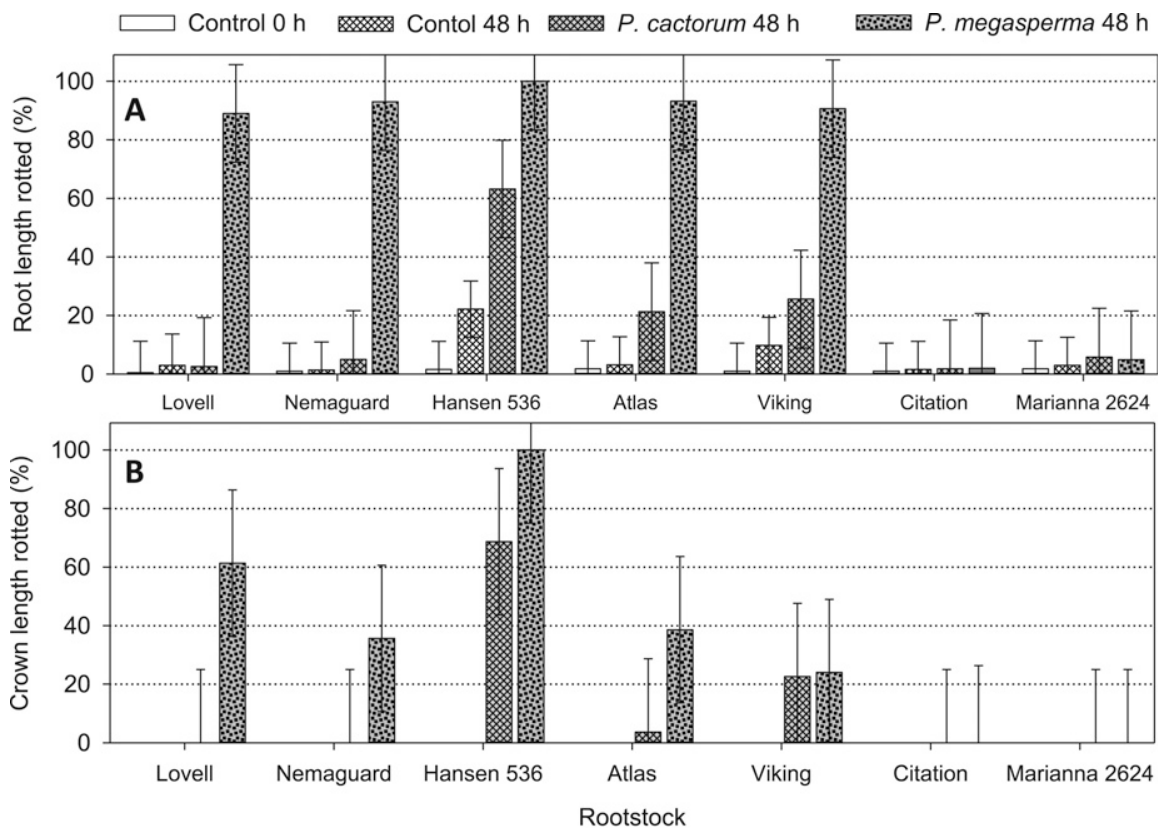

Fig. 2. Relative resistance of rootstocks in trial 2 to (A) root rot and (B) crown rot caused by two species of Phytophthora. The rootstocks were transplanted into noninfested soil (control) or soil infested with the indicated species of Phytophthora. Depending on the inoculum treatment, plants were either subjected to no soil flooding $(0 \mathrm{~h})$ or biweekly soil flooding for $48 \mathrm{~h}$. Three months after transplanting, the rootstocks were washed free from the potting soil and evaluated for severity of root and crown rot. Error bars are $95 \%$ confidence intervals.
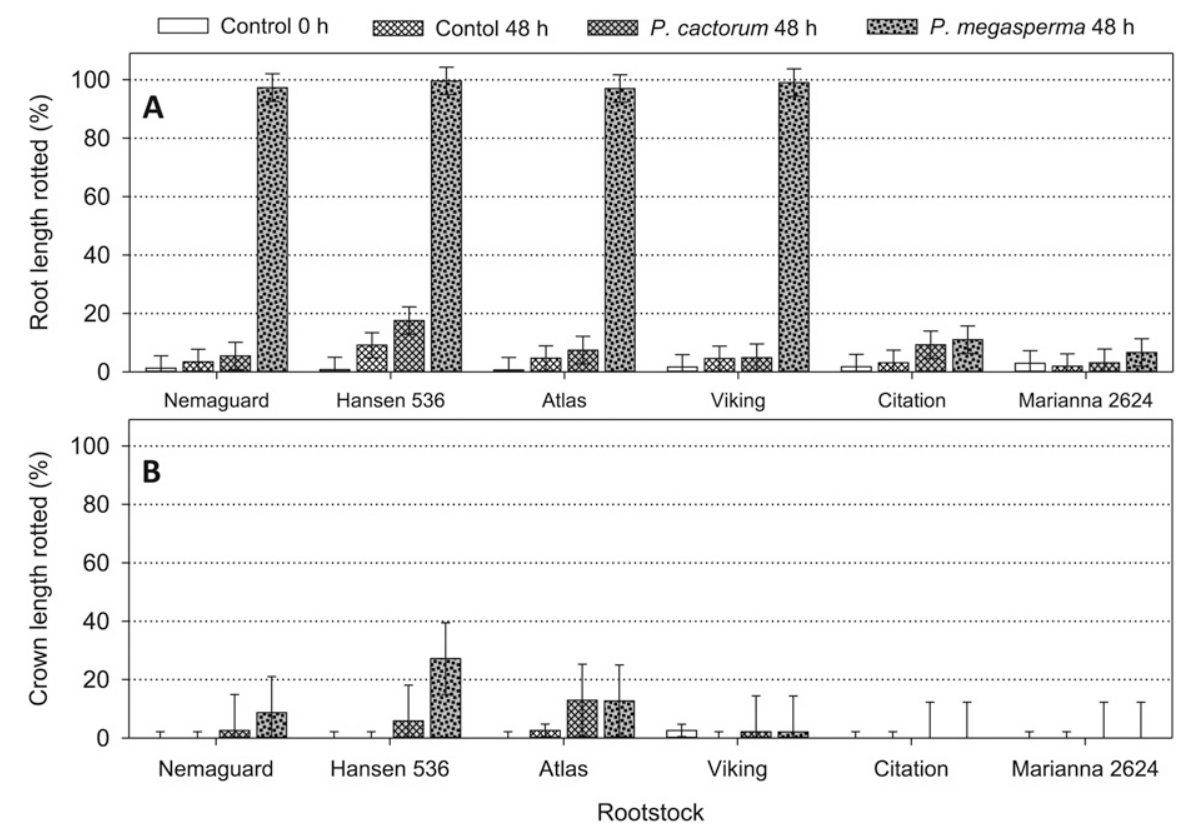

Fig. 3. Relative resistance of rootstocks in trial 3 to (A) root rot and (B) crown rot caused by two species of Phytophthora. The rootstocks were transplanted into noninfested soil (control) or soil infested with the indicated species of Phytophthora. Depending on the inoculum treatment, plants were either subjected to no soil flooding $(0 \mathrm{~h})$ or biweekly soil flooding for $48 \mathrm{~h}$. Three months after transplanting, the rootstocks were washed free from the potting soil and evaluated for severity of root and crown rot. Error bars are $95 \%$ confidence intervals.

Empyrean 1), peach $\times$ almond (i.e., rootstocks Bright Hybrid 5 and 106; Garnem; and Hansen 536), (peach $\times$ almond) $\times$ peach (i.e., rootstocks Tempropac and PAC 9908-02), and plum $\times$ almond (i.e., rootstock Rootpac-R). As in trial 4, the other plum hybrids (rootstocks Controller 5; Krymsk 1, 2, 9, and 86; Myrobalan; and
Marianna 2624) developed negligible crown rot in trial 5.

\section{Discussion}

This study examined resistance to $P h y$ tophthora species among multiple sets of 
rootstocks for almond and other stone fruit trees. The sets included widely used standards, such as 'Nemaguard', 'Lovell', 'Hansen 536', 'Marianna 2624', and 'Myrobalan', as well as less used or relatively new rootstocks. In each of the five trials, the rootstocks tested represented diverse genetic backgrounds, e.g., with almond, peach, plum, and hybrids of these species as parents. In the evaluations of resistance, an effort was made to represent species of Phytophthora that have been prevalent as root and crown rot pathogens of cultivated Prunus species in California. Large differences in resistance of the rootstocks to the Phytophthora species were detected. The results of the testing have immediate implications for orchard-based rootstock selection and testing as well as long-range implications for rootstock breeding and genetics.

Among the findings with immediate implications, it was determined that 'Hansen 536' is particularly susceptible to $P$. cactorum, $P$. citricola, and $P$. megasperma. Indeed, as the almond industry has shifted toward the use of 'Hansen 536' rootstock, early observations suggesting such susceptibility (Kester and Grasselly, 1987) have been borne out, especially in young orchards. Our results suggest that in orchards with a persistent history of tree losses due to crown and root rot associated with these species of Phytophthora, growers may reduce the disease incidence by using an acceptable rootstock with lower susceptibility to the pathogens. However, in trials 4 and 5, which evaluated resistance to the newly reported pathogen $P$. niederhauserii, rootstocks with peach and peach $\times$ almond backgrounds were all highly susceptible to the pathogen. It is too early to tell whether this broad susceptibility to $P$. niederhauserii among the tested peach and peach $\times$ almond hybrids will be manifested in California orchards, but our results suggest that this is important to monitor. To date, reported detections of the pathogen have been limited to peach $\times$ almond hybrid rootstocks and almond rootstock (Browne et al., 2015a; Kurbetli; and Değirmenci, 2012; Pérez-Sierra et al., 2010).

The high levels of resistance we detected among plum hybrid rootstocks to Phytophthora species may have long-range implications for rootstock breeding. 'Marianna 2624' was unique in these trials, being the only rootstock that developed no significant levels of root or crown rot with any of the Phytophthora species tested. Although 'Marianna 2624' is known for its partial resistance to Armillaria, tolerance of poorly drained soils, and good anchorage in addition to its resistance to Phytophthora species, it has horticultural drawbacks, including graft incompatibility with 'Nonpareil' almond and propensities for suckering, low tree vigor, and poor performance at some Prunus replant sites (Browne et al., 2006; Kester and Grasselly, 1987). Our findings suggest that it may be rewarding to examine the genetic basis of resistance to Phytophthora spp in 'Marianna 2624'; the resistance may be
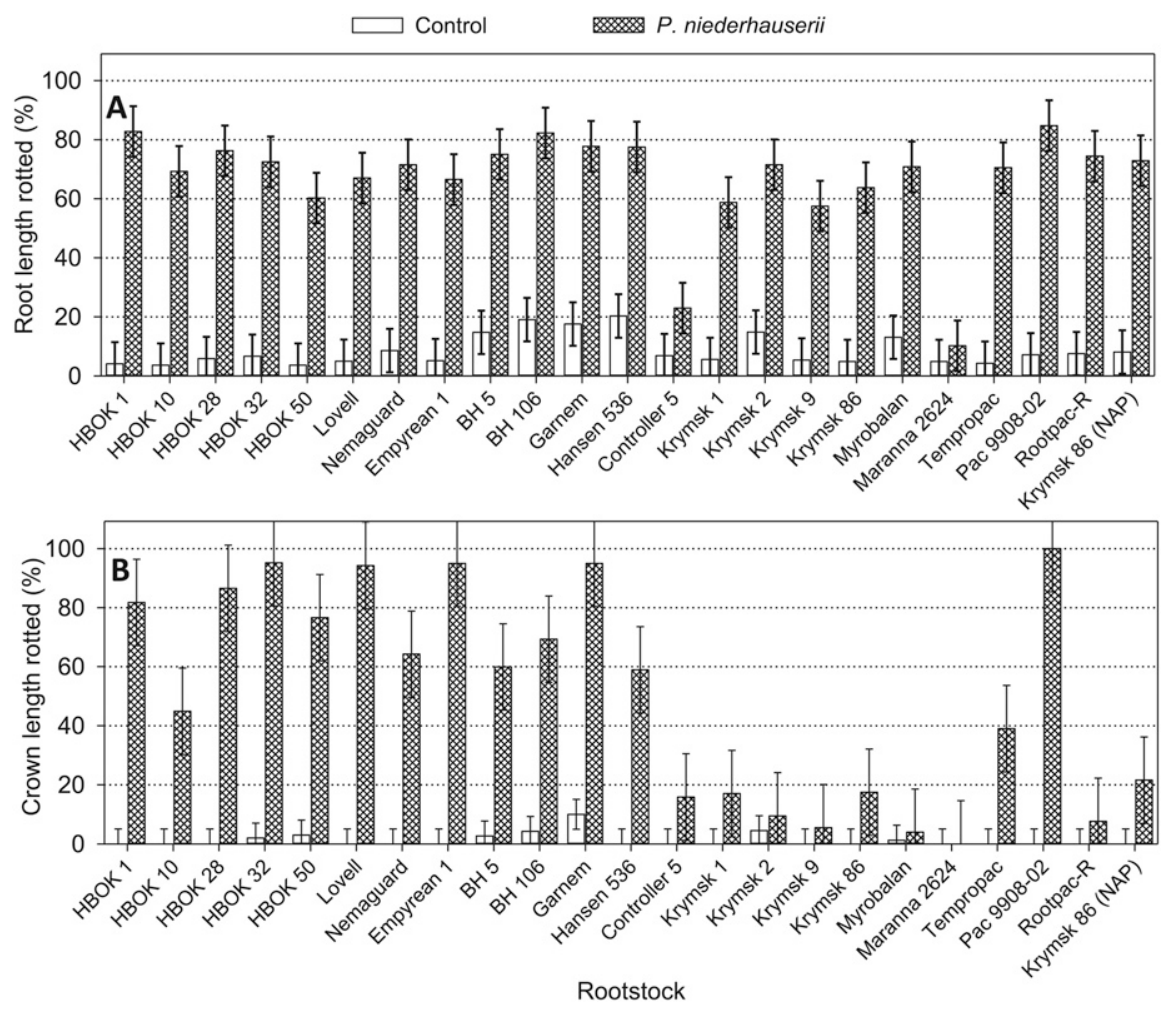

Fig. 4. Relative resistance of rootstocks in trial 4 to (A) root rot and (B) crown rot caused by Phytophthora niederhauserii. The rootstocks were transplanted into noninfested soil (control) or soil infested with the pathogen. All plants were subjected to biweekly soil flooding for $48 \mathrm{~h}$. Two months after transplanting, the rootstocks were washed free from the potting soil and evaluated for severity of root and crown rot. "NAP" designation after second Krymsk 86 on the $x$ axis indicates plants supplied by nursery 3 (North American Plants, Inc., Lafayette, OR); plants labeled "Krymsk 86 " only were from nursery 2 . Error bars are $95 \%$ confidence intervals.
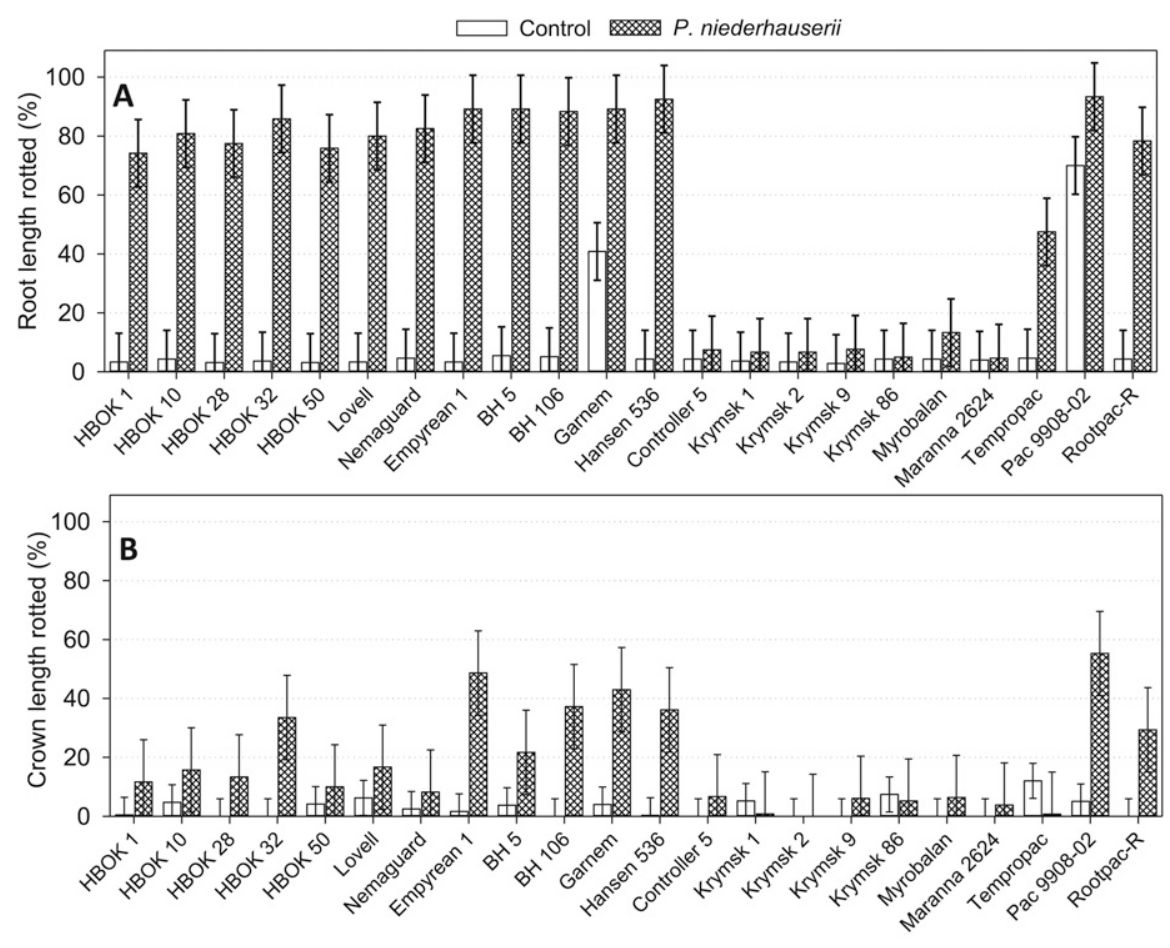

Rootstock

Fig. 5. Relative resistance of rootstocks in trial 5 to (A) root rot and (B) crown rot caused by Phytophthora niederhauserii. The rootstocks were transplanted into noninfested soil (control) or soil infested with the pathogen. All plants were subjected to biweekly soil flooding for $48 \mathrm{~h}$. Two months after transplanting, the rootstocks were washed free from the potting soil and evaluated for severity of root and crown rot. Error bars are $95 \%$ confidence intervals. 
transferable to or obtainable in other rootstocks that offer horticultural advantages over 'Marianna 2624'.

Key features of our results were repeatable among trials, including the relatively high susceptibility of 'Hansen 536' to $P$. cactorum, $P$. citricola, and $P$. megasperma; the high resistance of 'Marianna 2624' to root and crown rot of all tested species; and the high levels of resistance of other plum hybrids to crown rot caused by all tested species. However, variation in response of some rootstocks was also apparent. For example, 'Hansen 536' expressed higher relative susceptibility to crown rot incited by $P$. megasperma in trial 2 than in trial 1 . In addition, 'Citation' developed some crown rot in soil infested with $P$. cactorum or $P$. megasperma in trial 1 but not in trial 2 or 3 . Conversely, 'Nemaguard' developed crown rot in soil infested with $P$. megasperma in trials 2 and 3 but not in trial 1 . In soil infested with $P$. niederhauserii, several of the plum hybrid rootstocks that developed moderate levels of root rot in trial 4 did not do so in trial 5. It is uncertain what contributed to these variations in apparent susceptibility, but age of the plants, conditions in the greenhouse, and seasonal fluctuations in host susceptibility were likely contributing factors. Previous studies have reported that such factors can have large impacts on disease severity (Browne and Mircetich, 1996; FélixGastélum and Mircetich, 2005b, 2005c; Matheron and Mircetich, 1985). Our results demonstrate the importance of repeated experiments in assessing the resistance of Prunus rootstocks to Phytophthora species under various conditions; the approach can facilitate discrimination between spurious and consistent effects.

\section{Literature Cited}

Abad, Z.G., J.A. Abad, S.O. Cacciola, A. Pane, R. Faedda, E. Moralejo, A. Pérez-Sierra, P. AbadCampos, L.A. Alvarez-Bernaola, J. Bakonyi, A. Józsa, M.L. Herrero, T.I. Burgess, J.H. Cunnington, I.W. Smith, Y. Balci, C. Blomquist, B. Henricot, G. Denton, C. Spies, A. Mcleod, L. Belbahri, D. Cooke, K. Kageyama, S. Uematsu, I. Kurbetli, and K. Değirmenci. 2014. Phytophthora niederhauserii $\mathrm{sp}$. nov., a polyphagous species associated with ornamentals, fruit trees and native plants in 13 countries. Mycologia 106:431-447.

Broadbent, P., M. Barkley, M. Sriskanthadas, and C. Kaldor. 1996. Susceptibility of low chill peach rootstocks to Phytophthora spp. Austral. J. Expt. Agr. 36:111-116.

Browne, G., L. Schmidt, and G. Brar. 2015a. First report of Phytophthora niederhauserii causing crown rot of almond (Prunus dulcis) in California. Plant Dis. 99:1863.
Browne, G.T. and H.E. Becherer. 2000. Relative resistance to Phytophthora spp. among some rootstocks for almond. Phytopathology 90:S10.

Browne, G.T., R.H. Beede, and L.S. Schmidt 2012. Irrigation water relation to the health of deciduous fruit and nut crops. In: C. Hong and G. Moorman (eds.). Biology, detection and management of plant pathogens in irrigation water. APS Press, St. Paul, MN.

Browne, G.T., J.H. Connell, and S.M. Schneider. 2006. Almond replant disease and its management with alternative pre-plant soil fumigation treatments and rootstocks. Plant Dis. 90:869-876.

Browne, G.T. and M.A. Doster. 2002. Phytophthora diseases, p. 3-6. In: B. Teviotdale, T. Michailides, and J. Pscheidt (eds.). Compendium of temperate nut crops diseases. The American Phytopathological Society, St. Paul, $\mathrm{MN}$.

Browne, G.T., C.A. Leslie, J.A. Grant, R.G. Bhat, L.S. Schmidt, W.P. Hackett, D.A. Kluepfel, R. Robinson, and G.H. McGranahan. 2015b. Resistance to species of Phytophthora identified among clones of Juglans microcarpa $\times$ J. regia. HortScience 50:1136-1142.

Browne, G.T. and S.M. Mircetich. 1995. Phytophthora root and crown rots, p. 38-40. In: J.M. Ogawa, E.I. Zehr, G.W. Bird, D.F. Ritchie, K. Uriu, and J.K. Uyemoto (eds.). Compendium of stone fruit diseases. The American Phytopathological Society, St. Paul, MN.

Browne, G.T. and S.M. Mircetich. 1996. Effects of month of inoculation on severity of disease caused by Phytophthora spp. in apple root crowns and excised shoots. Phytopathology 86:290-294.

Browne, G.T., M. Viveros, L. Ferguson, and D. Kester. 1998. Diverse symptoms and tree losses caused by Phytophthora spp. in California almonds. Proceedings of the second international symposium on pistachios and almonds, Davis, CA, 24-29 Aug. 1997. Vol. 470, p. $570-575$.

Browne, G.T. and M.A. Viveros. 1999. Lethal cankers caused by Phytophthora spp. in almond scions: Specific etiology and potential inoculum sources. Plant Dis. 83:739-745.

Day, L.H. 1953. Rootstocks for stone fruits. Calif. Agr. Expt. Sta. 736:1-75.

Elena, K. and K. Tsipouridis. 2000. Evaluation of resistance of stone fruit rootstocks to Phytophthora crown rot. J. Phytopathol. 148:365-369.

Félix-Gastélum, R. and S.M. Mircetich. 2005a. Influence of flooding duration on the development of root and crown rot of lovell peach (Prunus persica (L.) Batsch) caused by three different Phytophthora species. Rev. Mex. Fitopatol. 23:33-41.

Félix-Gastélum, R. and S.M. Mircetich. 2005b. Influence of soil temperature on root and crown rot of Lovell peach (Prunus persica (L.) Batsch) caused by four species of Phytophthora. Rev. Mex. Fitopatol. 23:268-274.

Félix-Gastélum, R. and S.M. Mircetich. 2005c. Seasonal variation in susceptibility of Lovell peach (Prunus persica (L.) Batsch) to Phytophthora cactorum (Leb. and Cohn) Schroet., $P$. cinnamomi Rands, and P. citricola Sawada. Rev. Mex. Fitopatol. 23:294-299.

Gradziel, T.M. 2009. Almond, p. 1-32. In: S.M. Jain and P.M. Priyadarshan (eds.). Breeding plantation crops. Springer, New York.

Guzman, G., B.A. Latorre, R. Torres, and W.F. Wilcox. 2007. Relative susceptibility of peach rootstocks to crown gall and Phytophthora root and crown rot in Chile. Cienc. Investig. Agrar. $34: 31-40$.

Harvey, I.C. and M. Braithwaite. 1982. Records of fungal plant diseases in New Zealand. N. Z. J. Agr. Res. 25(3):435-442.

Hoagland, D. 1928. The water-culture method for growing plants without soil. Univ. California, College Agr., Agr. Expt Sta., Berkeley, CA.

Kannwischer, M.E. and D.J. Mitchell. 1978. The influence of a fungicide on the epidemiology of black shank of tobacco. Phytopathology 68:1760-1765.

Kester, D.E. and C. Grasselly. 1987. Almond rootstocks, p. 265-293. In: R.C. Rom and R.F. Carlson (eds.). Rootstocks for fruit crops. John Wiley and Sons, New York.

Kurbetli, I. and K. Değirmenci. 2012. Phytophthora spp. causing root and crown rot of almond in Central Anatolian region in Turkey. Bitki Koruma Bul. 52:299-312.

Matheron, M.E. and S.M. Mircetich. 1985. Seasonal variation in susceptibility of Juglans hindsii and Paradox rootstocks of English walnut trees to Phytophthora citricola. Phytopathology 75:970-972.

Matkin, O.A., P.A. Chandler, and K.F. Baker. 1957. The U.C.-type soil mixes, p. 68-85. In: K.F. Baker (ed.). UC system for producing healthy container-grown plants. University of California, Berkeley, CA.

Moreno, M.A. 2004. Breeding and selection of Prunus rootstocks at the Aula Dei Experimental Station, Zaragoza, Spain. Acta Hort. 658:519-528.

NASS. 2015. California agricultural statistics 2013 crop year. USDA NASS.

Pérez-Sierra, A., M. León, L.A. Álvarez, S. Alaniz, M. Berbegal, J. García-Jiménez, and P. Abad-Campos. 2010. Outbreak of a new Phytophthora sp. associated with severe decline of almond trees in eastern Spain. Plant Dis. 94:534-541.

Reighard, G.L., W.C. Newall, Jr., and D.W. Cain. 1989. Screening Prunus germplasm for potential rootstocks for South Carolina replant sites. Acta Hort. 254:287-290.

Schmidt, L.S., R.G. Bhat, D.A. Kluepfel, and G.T. Browne. 2012. Resistance to Phytophthora in new rootstocks for almond and stone fruits. Phytopathology. 102:S4.106. In: abstr.).

Wicks, T. and T. Lee. 1986. Phytophthora crown rot of almond trees. Austral. J. Agr. Res. 37:277-287.

Wilcox, W.F. and M.A. Ellis. 1989. Phytophthora root and crown rots of peach trees in the eastern Great Lakes region. Plant Dis. 73:794-798.

Wilcox, W.F. and S.M. Mircetich. 1985. Pathogenicity and relative virulence of seven Phytophthora spp. on Mahaleb and Mazzard cherry. Phytopathology 75:221-226. 